ACTA UNIVERSITATIS LODZIENSIS

FOLIA LITTERARIA POLONICA 1(47) 2018

http://dx.doi.org/10.18778/1505-9057.47.02

Halyna Dubyk*

\title{
Jewhen Małaniuk - ukraiński pisarz obozowy
}

Mówienie o ukraińskim poecie Jewhenie Małaniuku jako o pisarzu obozowym jest uprawnione z dwóch powodów. Pierwszy, bardziej oczywisty, to fakt, że jego debiut literacki miał miejsce w obozie dla internowanych żołnierzy Ukraińskiej Republiki Ludowej w roku 1923. Powód drugi, wymagający głębszej egzegezy, wynika ze swoistego obrazowania i nietypowego - zarówno na gruncie ukraińskim, jak i polskim - ujmowania tematyki stepowej. Przybliżenie obydwu kwestii należy poprzedzić wzmianką historyczną objaśniającą specyfikę wspomnianego obozu, którego powstanie finalizowało krótki okres militarnej współpracy polsko-ukraińskiej w wojnie z bolszewikami.

22 kwietnia 1920 roku marszałek Józef Piłsudski podpisał z Głównym Atamanem Ukraińskiej Republiki Ludowej, Symonem Petlurą, umowę polityczną, która stanowiła faktyczne uznanie nowopowstałego państwa ukraińskiego z granicą na rzece Zbrucz. Dwa dni później zawarto konwencję wojskową, stwierdzającą wspólne prowadzenie akcji militarnych przez sprzymierzone wojska polskie i ukraińskie. Tym samym trzy dywizje URL, a w ich składzie oficer Sztabu Generalnego Jewhen Małaniuk, wzięły udział w wojnie polsko-bolszewickiej. Wyprawa kijowska (najpopularniejsze określenie polsko-ukraińskiej ofensywy na Kijów podczas wojny z bolszewikami) zakończyła się fiaskiem. Wśród głównych powodów niepowodzenia tej operacji wojskowej można wymienić błędy taktyczne dowództwa polskiego oraz skromne liczebnie siły ukraińskie zaangażowane w operację. W istocie odezwa Atamana Petlury o ochotnicze zasilenie szeregów wojska ukraińskiego nie odniosła zamierzonego skutku. Wprawdzie w interesie zubożałych i zmęczonych przedłużającą się wojną chłopów ukraińskich było ustanowienie stabilnej władzy, która zapewniłaby spokój i porządek, lecz poddawani propagandzie bolszewickiej, obawiali się powrotu "polskich panów" i odebrania rozparcelowanych majątków. Jan Jacek Bruski podkreśla, że niechęć Ukraińców wobec mobilizacji była w pewnym sensie zrozumiała - „chłop

* Dr, adiunkt; Uniwersytet Kardynała Stefana Wyszyńskiego, Wydział Nauk Humanistycznych, Katedra Modernizmu Europejskiego; ul. Dewajtis 5, 01-815 Warszawa; halyna.dubyk@ gmail.com. 
nie chciał mieszać się do walki [wychodząc z założenia, że] «mnie z chłopa nie degradują»" ". Ponadto znaczna część społeczeństwa ukraińskiego nie wierzyła, by Polacy byli w stanie dać odpór bolszewikom. W związku z tym liczebność Ukraińców we wspólnej akcji przeciw bolszewickim siłom była nieznaczna w zestawieniu z resztą zaangażowanych w ofensywę sił, co strona polska uznawała za główną przyczynę niepowodzenia wyprawy kijowskiej. Dowództwo ukraińskie zrzucało natomiast odpowiedzialność na Polskę, która nie przeprowadziła na czas mobilizacji na terenie Ukrainy ${ }^{2}$.

W kontekście interesującej nas kwestii istotny jest fakt, że walki na całym froncie ustały w październiku, po wejściu w życie polsko-sowieckiego rozejmu. Niegdysiejszym sojusznikom pozostawiono możliwość opuszczenia terenów przyznanych Polsce układem rozejmowym, jednak część wojsk URL zdecydowała się na dalszą, samotną walkę z bolszewikami, która skazana była na porażkę. Ostateczny odwrót przed napierającymi siłami bolszewickimi miał miejsce w listopadzie 1920 roku. Przekraczający rzekę Zbrucz oraz składający broń sojusznicy podlegali internowaniu oraz odesłaniu do obozów rozsianych po całej Polsce, m.in. do Kalisza, Aleksandrowa Kujawskiego, Pikulic, Częstochowy. Większość badaczy jest zgodna, że ustalenie dokładnej liczby ówczesnych uchodźców jest w zasadzie niewykonalne. W ciągu dwóch ostatnich miesięcy 1920 roku granicę Rzeczypospolitej przekroczyło 40-45 tysięcy osób z Ukrainy³. Jak pisze Zbigniew Karpus:

W ocenie strony polskiej internowano wówczas około 19,5 tysiąca Ukraińców, w tym 4280 oficerów, 14006 żołnierzy i 1165 cywilów (członków rodzin). Dowództwo ukraińskie utrzymywało jednak, że w Polsce znalazło się ok. 27 tys. żołnierzy. Niektórzy historycy ukraińscy mówią też o 7 tys. cywilów, w tym 2,5 tys. urzędników państwowych ${ }^{4}$.

\footnotetext{
${ }^{1}$ J.J. Bruski, Petlurowcy. Centrum Państwowe Ukraińskiej Republiki Ludowej na wychodźstwie (1919-1924), Arcana, Kraków 2004, s. 166.

2 Tamże, s. 166.

${ }^{3}$ Tamże, s. 239.

${ }^{4}$ W książce Zbigniewa Karpusa Wschodni sojusznicy Polski w wojnie 1920 roku czytamy, że według szacunków polskich historyków internowano wówczas „około 19,5 tysięcy wojskowych Ukraińców (i 7 tysięcy koni) [...]. Z powodu trudnej sytuacji panującej w rejonie koncentracji internowanych (brakowało żywności, pomieszczeń itp.) niektórzy z Ukraińców i Rosjan, nie chcąc, aby ich wysłano do polskich obozów, uciekali za Zbrucz na stronę sowiecką". Z. Karpus, Wschodni sojusznicy Polski w wojnie 1920 roku: oddziały wojskowe ukrainskie, rosyjskie, kozackie i biatoruskie w Polsce w latach 1919-1920, Wydawnictwo Uniwersytetu Mikołaja Kopernika, Toruń 1999, s. 57. Bardziej szczegółową charakterystykę internowanej grupy zamieszcza tenże autor w artykule Zdradzeni sojusznicy. Oddziaty ukraińskiej republiki ludowej w roku 1920 i ich dalsze losy [online], https://ioh.pl/artykuly/pokaz/zdradzeni-sojusznicy-odziay-ukraiskiej-republiki-ludowej-w-roku--i-ich-dalsze-losy,1066/ [dostęp: 24.11.2016].
} 
Rok później, po licznych przesunięciach, Ukraińców internowano już jedynie w Szczypiornie, Kaliszu i Strzałkowie. Ostatnich petlurowców wypuszczono z obozu w roku 1924, od tej pory stawali się emigrantami politycznymi ${ }^{5}$.

Powyższe określenie, zapożyczone od Karpusa, jest istotne w odniesieniu do bohatera mojego tekstu. Jewhen Małaniuk, urodzony na Chersońszczyźnie w roku 1897, który przed wojną pisywał utwory po rosyjsku, lecz nie ogłaszał ich drukiem, znalazłszy się w obozie dla internowanych żołnierzy, skoncentrował się na pracy kulturalno-literackiej. Życie kulturalne w obozach było dość ożywione i starannie stymulowane przez dowództwo, gdyż stanowiło możliwość aktywizacji skazanych na wegetację byłych żołnierzy, pozwalało też kontrolować ich morale. Tu warto nadmienić, że dużo większym wyzwaniem dla internowanych było zapanowanie nad rozterkami psychicznymi niż sprostanie niedostatkom materialnym. Często w tym samym obozie przetrzymywano internowanych byłych sojuszników z URL obok radzieckich jeńców, wykpiwających ukraińskich żołnierzy. Już w grudniu 1920 roku Polskie Ministerstwo Spraw Wojskowych zaleciło prowadzenie w republikach obozowych ,prac oświatowych, zajęć gimnastycznych, kółek dramatycznych, etc."'6. W kaliskim obozie, gdzie przebywał Małaniuk, działało literacko-artystyczne stowarzyszenie „Wesełka”, które wydawało czasopismo o tym samym tytule, ukazywały się wojskowo-literacki magazyn „Wijśkowyj Surmacz” oraz czasopismo „Nasza Zoria”, działał teatr, chór oraz studio artystyczne ${ }^{7}$. Małaniuk dość szybko włączył się do prac kulturalno-literackich, artykuły sygnowane jego nazwiskiem zaczęły ukazywać się w obozowych periodykach od roku 1921. Następnie został współredaktorem czasopisma „Wesełka”, zaś w roku 1923 zadebiutował jako poeta tomikiem wierszy Ozimina (tytuł oryginału: Ozymyna), wydanym wespół z dwoma innymi internowanymi żołnierzami. Również w kaliskim obozie przygotował do druku dwa tomy poetyckie, które ukazały się kolejno w roku 1925 oraz w 1926, kiedy Małaniuk wyjechał już na studia do Czechosłowacji. Od chwili debiutu literackiego można i należy mówić o nim jako o poecie emigracyjnym (ponownie nawiązuję do przywołanego już określenia Karpusa), choć na przykład Edward Kasperski uważał, że Małaniuk, zostając w Polsce, nie tylko zrezygnował z powrotu do Ukrainy Radzieckiej, lecz także „odmówił uznania za własną ojczyznę II Rzeczpospolitą, gdzie przecież na Wołyniu, Podolu czy Pokuciu żyło ponad 5 milionów Ukraińców”, zatem „kategoria emigranta w tej sytuacji mogła mieć ograniczone - do pewnego stopnia subiektywne i metaforyczne - zastosowanie"8.

\footnotetext{
${ }^{5}$ Z. Karpus, Zdradzeni sojusznicy...

${ }^{6}$ Z. Karpus, Jeńcy i internowani rosyjscy i ukraińscy na terenie Polski w latach 1918-1924, Wydawnictwo Adam Marszałek, Toruń 1999, s. 136-137.

${ }^{7}$ Zob. tamże, s. 139.

${ }^{8}$ E. Kasperski, Jewhen Małaniuk i emigracyjne pogranicza kultur. Paralele ukraińsko-polskie, w: Literackie Kresy i bezkresy, pod red. K.R. Łozowskiej i E. Tierling, Wydawnictwo Naukowe Uniwersytetu Szczecińskiego, Szczecin 2000, s. 262.
} 
Po studiach w Podiebradach poeta wrócił do Polski i zamieszkał w Warszawie. Opublikował kolejne tomy poetyckie, pisał artykuły do licznych polskich czasopism, pracował kolejno w bibliotece Ministerstwa Rolnictwa, jako inżynier hydrotechnik w Urzędzie Miejskim i nauczyciel w seminarium prawosławnym. Utrzymywał wówczas bliskie kontakty z polskimi twórcami, przyjaźnił się z Jarosławem Iwaszkiewiczem, Julianem Tuwimem oraz Stempowskimi - Stanisławem i Jerzym, ten ostatni zresztą został ojcem chrzestnym jedynego syna Małaniuka ${ }^{9}$. Ukraińscy badacze podkreślają, że był jednym z niewielu emigrantów unikających gettowości i wiążą ten fakt $\mathrm{z}$ wieloetnicznym pochodzeniem poety, w którym płynęła krew serbska, mołdawska, polska i, rzecz jasna, ukraińska ${ }^{10}$. Nawet w kręgu ukraińskich literaturoznawców przyjęło się stwierdzenie (za samym Małaniukiem), że traktował Polskę jako swoją drugą ojczyznę. Zdaje się jednak, że należy wyodrębnić kilka czynników, które utrzymywały w świadomości, a co za tym idzie również w twórczości poety, kategorię 'obcości' przez cały okres międzywojenny (powojenna emigracja do Stanów Zjednoczonych wyzwoliła inne konotacje, ale ta kwestia winna być analizowana osobno).

Pierwszym czynnikiem jest niewątpliwie stygmat poobozowy i towarzysząca internowaniu demonstracyjna zamiana oręża, jakiej dokonał rozbrojony oficer, koncentrując się na pracy literackiej. Pierwszy samodzielny tom poetycki wydany przez Małaniuka w Podiebradach nosił tytuł Sztylet czy stylos. Tytułowy utwór sygnalizował konieczność zmiany sposobu walki, choć walka ta bynajmniej nie była naznaczona wiarą w zwycięstwo:

Sztylet czy stylos - nie pojmuję, na różne strony

tragiczne szale ciągle się schylają

nie osadzony, nie zakotwiczony,

po obu stronach brzegi piękna mnie mijają ${ }^{11}$.

Wprawdzie w innych tekstach z tego tomu pobrzmiewa większe przekonanie co do celowości „zmiany oręża”' ${ }^{2}$, jednak sama decyzja o niej do cna pozbawiona była optymizmu. Dysponujemy niewielkim zespołem utworów poetyckich bezpośrednio odnoszących się do wydarzeń z listopada 1920. O ile mi wiadomo, owe wiersze nie były przekładane na polski, przytoczę zatem na zasadzie opisu bądź

\footnotetext{
${ }^{9}$ Więcej na temat relacji Małaniuka z polskimi twórcami zob.: H. Dubyk, Polskie kontakty literackie Jewhena Małaniuka, „Pamiętnik Literacki” 2010, z. 3, s. 73-99.

${ }^{10}$ L. Kucenko, Dominus Malaniuk: tło i postat', Centralno-Ukrajinskie Wydawnyctwo, Kirowohrad 2001, s. 22.

${ }^{11}$ J. Małaniuk, Sztylet czy stylos, w: tenże, Sztylet czy stylos, Kijów, Podiebrady 1925, s. 3. Tłum. H.D.

12 „Pojmiesz, ku jakim wielkim chwilom / krew pulsowała w głębi żył, / czemu sztyletem był mój stylos, / czemu stylosem sztylet był". J. Małaniuk, Napis na księdze wierszy, przeł. J. Łobodowski, „Biuletyn Polsko-Ukraiński” 1937, nr 29, s. 328.
} 
wyrywkowego cytowania poruszaną w kilku z nich problematykę, sygnalizując okres powstania i/lub publikacji. W tomie Zielnik (tytuł oryginału: Herbarij) z roku 1926 znalazł się cykl trzech utworów, Pod obcym niebem, które podejmują tematykę wyobcowania i straconych nadziei - wiersze jednak są osobiste, nostalgiczne, naznaczone tęsknotą za małą ojczyzną i nie dotykają spraw ogólnych. W tym też tomie opublikowano najbardziej dojmujący utwór z roku 1920 - można zatem przypuszczać, że dokumentujący opuszczenie Ukrainy - zatytułowany Wyjście. Wiersz ten otwierał blok poetycki opublikowany przez Małaniuka w obozowym ,tomiku trzech” - w Oziminie:

Złowróżbne zleciały się ptaki

Krążąc nad tym smutnym pochodem

I płakał pociąg: Na Zachód...

Na Zachód... Na Zachód,

Poganiany śmiejącym się Wschodem ${ }^{13}$.

Obraz uciekającego na zachód pociągu powróci w kolejnym utworze z tomu Ziemia i żelazo (tytuł oryginału: Zemla j zalizo) z roku 1930. Wiersz zatytułowany 13 listopada 1920 przynosi topikę stepowo-tatarską, jednak ocalające ,wyjście" jest traktowane zarazem jako zdradziecka ucieczka z ,apokalipsy piękna stepowego". Występujące w nim zderzenie zachodniego i wschodniego rozumienia losu jest sygnałem prawdziwego dramatu, z jakim przyjdzie się mierzyć nowym uchodźcom.

Jak widać, owo dramatyczne doświadczenie opuszczenia, rozbrojenia, a z punktu widzenia żołnierzy URL również zdrady, nie przełożyło się znacząco na Małaniukową twórczość w sensie bezpośrednim. Obraz obozu, w którym spędził poeta kilka lat, nie pojawił się w jego utworach ani razu, pozostałe kwestie związane z tym etapem jego życiorysu (zdrada, rozbrojenie, utrata nadziei na niepodległość ojczyzny) również były transponowane literacko bardzo oszczędnie. Mamy jednak sygnały świadczące o trwałym urazie, które potwierdzają, że symboliczna „zmiana oręża” nie odbyła się wyłącznie w sferze pojęć. Małaniuk od 1920 roku, o ile mi wiadomo z różnojęzycznych źródeł, nigdy nie wziął do ręki broni, choć okazji po temu nie brakowało. Wprawdzie Antoni Serednicki w Esejach polsko-ukraińskich pisał, że w obronie Warszawy w 1939 roku brał udział m.in. „oficer petlurowski i poeta Jewhen Małaniuk”14, zdaje się jednak, że fakty mogły wyglądać inaczej. W wydanym w roku 2008 tomie zapisków diarystycznych Małaniuka czytamy następującą wzmiankę, opatrzoną datą 7 września 1939:

${ }^{13}$ J. Małaniuk, Ischod [Wyjście], w: tenże, Powernennia, Swit, Lwów 2005, s. 29. Tłum. H.D.

${ }^{14}$ A. Serednicki, Eseje polsko-ukraińskie, [b.w.], Warszawa 1996, s. 61. 
„Bezczynność mężczyzny w czasie wojny na dłuższą metę jest nie do wytrzymania. Dziś w nocy wydawało mi się, że u mnie zanika penis i wyrasta vagina... Dziwny sen [...] czyż [...] nie jest symboliczny?"15. W kontekście zacytowanego fragmentu dziennika można uzasadnić tezę, że w XX wieku nie mogło być dla Małaniuka mowy o wytrąceniu z rąk oręża. Tyle że z konieczności je zmieniono na... bardziej skuteczne.

Jeszcze będąc w obozie, Małaniuk dał wyraz poglądom, że w warunkach odpaństwowienia skoncentrowanie się na pracy literackiej jest jedynie słuszną alternatywą dla walki bezpośredniej. Powoływał się przy tym na doświadczenie polskich romantyków. W artykule $O$ losach emigracji, który ukazał się na łamach obozowego pisma, twierdził: „Historia polskiej emigracji to najlepsza lektura dla nas na obczyźnie"'16. Można jednak przypuszczać, że owo budowanie paraleli z polską Wielką Emigracją sięgało głębiej i oddziaływało na wyobraźnię pisarza dłużej. W roku 1933 na łamach „Wiadomości Literackich” ukazał się w przekładzie Juliana Tuwima wiersz Małaniuka Warszawa. Zacytuję fragment tego utworu, który wywołał spory rezonans w ukraińskiej prasie ukazującej się na terenach II RP:

Wpatrujesz się chmurnie, spiżowo,

Ponad piętra i ludzi i twarze,

Grzmi pod tobą, dygocąc miarowo,

Stolica w burzliwym rozgwarze.

W dali mewy wiślane krzyczą,

Fala brzegi piaszczyste liże,

Czarne miasto twoje, Mickiewiczu,

Eurazyjskim jest dla mnie Paryżem.

$[\ldots]$

W mgłach wyspiańskich Belweder, owiany

Petersburskim tumanem mrocznym.

W sennych oknach - czy to płomień, czy plamy?

Szare widmo - uroczyste czy uroczne?

I kiedy gałęzie zaskrzypią,

I wschód wionie ziębiącym nordem,

Wicher liśćmi Aleje zasypie,

Bruk wyściele mongolskim hordom.

15 J. Małaniuk, Notatnyky 1936-1939, Tempora, Kijów 2008, s. 65-66. Tłum. H.D.

16 J. Małaniuk, Pro doliu emigraciji, ,Nasza Zoria” 1922, nr 28, s. 19. Tłum. H.D. 
Leci, leci ordzewa liściasta,

Tatarskimi się kładzie kilimami.

Pilnuj, pilnuj swojego miasta,

Wartowniku spiżowy, Adamie! ${ }^{17}$

O ile lwowskie gazety z miejsca wszczęły larum, że poeta ukraiński głosi hymny pochwalne Polsce, chyli czoła przed Warszawą i dedykuje strofy „,spiżowemu wartownikowi”, Mickiewiczowi, o tyle sam autor dużo przytomniej konstatował w liście do przyjaciela: ,idioci i do tego podli idioci z «Dzwonów» opublikowali wyraźnie prowokacyjną i bezgranicznie głupią notatkę «Hymn na cześć Warszawy pióra J.M.». Przede wszystkim pióra Tuwima, a po drugie - co to za hymn? Przecież naród polski może się jedynie pogniewać o taki «hymn»" ${ }^{18}$. Jednocześnie byłoby niesprawiedliwością szukać źródeł ukrytej wrogości do Polski w ukraińskim nacjonalizmie, choć istotnie, Małaniuk, uznawany za najzdolniejszego emigracyjnego poetę swojego pokolenia, współtwórca i przywódca tzw. Praskiej Szkoły, autor oryginalnej liryki patriotycznej, był przez wiele lat bliskim współpracownikiem Dmytro Doncowa, czołowego ideologa ukraińskiego nacjonalizmu. W dorobku Małaniuka na próżno szukać utworów, które bezkrytycznie podnosiłyby sprawy ukraińskie i sprzyjały nieżyczliwej ocenie Polski. Wręcz przeciwnie - jego liryka poświęcona ojczyźnie częstokroć brzmiała jak najstraszniejsze oskarżenie. Poetyckie obrazy Ukrainy, które wyszły spod pióra Małaniuka nie miały pierwowzorów ani w literaturze polskiej, ani w ukraińskiej. Gdy sentyment i tęsknota za Ukrainą stanowiły dla niego niezmienny imperatyw twórczy, jego wizja stepów stawała się całkowicie wyzbyta sentymentalizmu ${ }^{19}$. Stale nawiązując do helleńskiej tradycji Ukrainy, która miała włączyć jego ojczyznę w krąg kultur śródziemnomorskich ${ }^{20}$ i skutecznie odgraniczyć od barbarzyńskiej, „tatarskiej” Rosji, niejednokrotnie mówił o swoim nieistniejącym kraju z wściekłą furią, która szokowała nawet najbardziej wyrozumiałych czytelników.

Ale owdzie była bujność, piękno, urok wonny jak stepowy kwiat:

${ }^{17}$ J. Małaniuk, Warszawa, przeł. J. Tuwim, „Wiadomości Literackie” 1933, nr 12, s. 1.

${ }^{18}$ Cyt. za: L. Kucenko, Krycewe stowo. Literaturnyj portret Jewhena Małaniuka, Wesełka, Kijów 2005, s. 33. Tłum. H.D.

${ }^{19}$ Jadwiga Sawicka pisze: „Małaniuk odrzucił Szewczenkowską romantyczną wizję stepu; wówczas, gdy we wczesnym okresie twórczości poeta ukazywał jego łagodne piękno, w obliczu klęski Petlury step stracił kształt, pogrążył się w chaosie". J. Sawicka, Wołyń poetycki w przestrzeni kresowej, Wydawnictwo DiG, Warszawa 1999, s. 91.

${ }^{20} \mathrm{~W}$ tym hellenocentryzmie Małaniuk podąża za wcześniejszymi rozpoznaniami ukraińskich historyków oraz kulturoznawców. Zob. np. O. Subtelnyj, Ukrajina. Istorija, Łybid', Kijów 1993, s. 21; M. Popowycz, Narys istoriji kultury Ukrajiny, ArtEk, Kijów 1999, s. 62. 
tutaj - ludu kalekiego piętno,

mać janczarów, co ją gwałci kat.

Ale owdzie, wydrapując ślepia,

jak wilczyca marła w walce; tu -

już każdemu chętna kto zaczepia...

dzikie ciało, kochające knut ${ }^{21}$.

Podkreślę też, że przytoczony fragment utworu z 1929 roku, niezwykle rzadko przedrukowywany w ukraińskich wydaniach poezji Małaniuka, nie wyczerpywał ataków na ojczyznę. Obraz antymatki wracał w środkowym (i zarazem szczytowym) okresie jego twórczości w różnych tekstach. Nawet stały przydomek, „Stepowa Hellada”, bywał przezeń podważany, sprowadzany do widmowego, demonicznego pierwiastka nieistniejącej upiorzycy:

A nie stepowa może Hellada

lecz piękna panna - umarła strzyga,

co serce czarnym nasyca jadem

a w północ głuchą ze snów się dźwiga ${ }^{22}$.

Badacze twórczości Małaniuka nigdy nie postawili tezy, która zdefiniowałaby źródła tego „okrucieństwa z nadmiaru miłości” w narracji patriotycznej poety. Przyjęto bez dyskusji przekonanie co do patriotycznej wymowy jego wierszy, pozwalającej na krytyczną ocenę ojczyzny i rodaków, a zatem również samego siebie, jako rzeczy samoistnej. Biorąc jednak pod uwagę niechęć Małaniuka wobec dosłownego zapisu przeżyć (rozczarowanie spowodowane finałem polsko-ukraińskiej współpracy militarnej jest rozproszone w różnych utworach i słabo czytelne), można zaryzykować tezę, że u podstaw surowych i okrutnych wierszy ukraińskich Małaniuka legło rozżalenie na nieskuteczność instytucjonalnego przeciwdziałania Historii. Zwracał się gorzkimi słowy nie tylko do nieistniejącej na mapie świata Ukrainy, lecz także do wszystkich i wszystkiego, co nie przeszkodziło napływowi nowych hord, tym razem sowieckich, na zaprzepaszczone stepy.

Po zakończeniu II wojny światowej Małaniuk wyemigrował do Ameryki. Nawiązał wówczas kontakt korespondencyjny z Jerzym Giedroyciem, publikował na łamach paryskiej „Kultury” artykuły i utwory poetyckie, jednak nigdy nie włączył się do fundamentalnych ,ukraińskich” inicjatyw redaktora. Ma się wrażenie, że podobnie jak w międzywojniu, kiedy rozumiejąc polską rację stanu i do-

${ }^{21}$ J. Małaniuk, Ukraińskie oczy, przeł. C. Jastrzębiec-Kozłowski. „Zet” 1936, nr 16, s. 4.

22 J. Małaniuk, A nie stepowa może Hellada, przeł. J. Czechowicz, „Zet” 1933/1934, nr 2, s. 3. 
ceniając ofertę Polski dla emigrantów, wolał nie zabierać stanowiska w sprawach, które nurtowały polskich ukrainofilów, a nawet nie nazywać wprost gmatwaniny osobistych uczuć i myśli. Byłyby, prawdopodobnie, zbyt gorzkie dla jego „drugiej ojczyzny”. Z drugiej strony uraz poobozowy, a może bardziej „pozdradziecki” - bo właśnie poczucie zdrady najmocniej towarzyszyło byłym żołnierzom URL w listopadzie 1920 roku - wpłynął na taką, a nie inną postawę poetycką, takie, a nie inne obrazy i motywy, których oryginalność, być może, wynika właśnie $\mathrm{z}$ oryginalności doświadczenia piszącego. Z grona byłych żołnierzy internowanych na terenach II RP, którzy w republikach obozowych uprawiali twórczość literacko-artystyczną, po rozformowaniu obozów w roku 1924 ,stylosem” na takim poziomie władał tylko jeden - Jewhen Małaniuk, oficer sztabu generalnego, adiutant głównodowodzącego Armią Naddnieprzańską, gen. Wasyla Tiutiunnyka, inżynier, a nade wszystko - poeta.

\section{Bibliografia}

Bruski Jan Jacek, Petlurowcy. Centrum Państwowe Ukrainskiej Republiki Ludowej na wychodźstwie (1919-1924), Wydawnictwo Arcana, Kraków 2004.

Dubyk Halyna, Polskie kontakty literackie Jewhena Małaniuka, „Pamiętnik Literacki” 2010, z. 3, s. 73-99.

Karpus Zbigniew, Jeńcy i internowani rosyjscy i ukraińscy na terenie Polski w latach 1918-1924, Wydawnictwo Adam Marszałek, Toruń 1999.

Karpus Zbigniew, Wschodni sojusznicy Polski w wojnie 1920 roku. Oddziaty wojskowe ukraińskie, rosyjskie, kozackie i białoruskie w Polsce w latach 1919-1920, Wydawnictwo Uniwersytetu Mikołaja Kopernika, Torun 1999.

Karpus Zbigniew, Zdradzeni sojusznicy. Oddziały ukraińskiej republiki ludowej w roku 1920 i ich dalsze losy [online], https://ioh.pl/artykuly/pokaz/zdradzeni-sojusznicy-odziay-ukraiskiej-republiki-ludowej-w-roku--i-ich-dalsze-losy,1066/ [dostęp: 24.11.2016].

Kasperski Edward, Jewhen Małaniuk i emigracyjne pogranicza kultur. Paralele ukraińsko-polskie, w: Literackie Kresy i bezkresy, pod red. Katarzyny R. Łozowskiej i Ewy Tierling, Uniwersytet Szczeciński, Szczecin 2000, s. 261-280.

Kucenko Leonid, Dominus Malaniuk: tło i postat', Centralno-Ukrajinśkie Wydawnyctwo, Kirowohrad 2001.

Kucenko Leonid, Krycewe słowo. Literaturnyj portret Jewhena Małaniuka, Wydawnictwo Wesełka, Kijów 2005.

Małaniuk Jewhen, A nie stepowa może Hellada, przeł. Józef Czechowicz, „Zet” 1933/1934, nr 2, s. 3.

Małaniuk Jewhen, Ischod, w: tenże, Powernennia, Wydawnictwo Swit, Lwów 2005, s. 29.

Małaniuk Jewhen, Napis na księdze wierszy, przeł. Józef Łobodowski, „Biuletyn Polsko-Ukraiński” 1937, nr 29, s. 328.

Małaniuk Jewhen, Notatnyky 1936-1939, Wydawnictwo Tempora, Kijów 2008.

Małaniuk Jewhen, Pro doliu emigraciji, „Nasza Zoria” 1922, nr 28, s. 19.

Małaniuk Jewhen, Sztylet czy stylos, w: Małaniuk Jewhen, Sztylet czy stylos, Wydawnictwo Kijów, Podiebrady 1925, s. 3. 
Małaniuk Jewhen, Ukraińskie oczy, przeł. Czesław Jastrzębiec-Kozłowski „Zet” 1936, nr 16, s. 4. Małaniuk Jewhen, Warszawa, przeł. Julian Tuwim, „Wiadomości Literackie” 1933, nr 12, s. 1. Popowycz Myrosław, Narys istoriji kultury Ukrajiny, Wydawnictwo ArtEk, Kijów 1999.

Sawicka Jadwiga, Wotyń poetycki w przestrzeni kresowej, Wydawnictwo DiG, Warszawa 1999. Serednicki Antoni, Eseje polsko-ukraińskie, [b.w.], Warszawa 1996.

Subtelnyj Orest, Ukrajina. Istorija, Wydawnictwo Łybid', Kijów 1993.

\section{Halyna Dubyk}

\section{Jewhen Malaniuk - internment camp Ukrainian writer}

\section{Summary}

The article exposes works of Jewhen Małaniuk, Ukrainian poet, who debuted in internment camp for soldiers of Ukrainian People's Republic situated in Poland. Disappointment caused by Ukraine's institutional impotence and also by disloyalty of Polish ally reflected in poet-soldier's peculiar literary picturing, which was permanently affected by post-camp syndrome.

Keywords: Jewhen Małaniuk; internment camp republics; Polish-Ukrainian literary relations; interwar period; patriotic lyric poetry 